\title{
ANALYSIS OF THE APPLICATION OF DIFFERENTIAL ACCOUNTING INFORMATION IN DECISION MAKING RECEIVING OR REJECTING SPECIAL ORDERS TO INCREASE CORPORATE PROFITS
}

\author{
Epi Fitriah', Yuni Rosdiana², Affandi Iss ${ }^{3}$, Helliana $^{4}$, Yola Septidiana ${ }^{5}$, \\ Faculty of Economics and Business, Islamic University, Bandung, \\ Jl. Tamansari No.1 Bandung Indonesia
}

\begin{abstract}
This study aims to determine the application of differential accounting information in decision making to accept or reject product special orders at Company X; The level of profit development in company $X$; The use of differential accounting information in decision making to accept or reject product-specific orders can increase profits in company $X$. The research method used in this research is the case study method and descriptive analysis. Data collection techniques using questionnaires, documentation and interviews. Data analysis using Likert scale and calculation of profit growth rate. Based on the results of the study note that the application of differential accounting information in decision making to accept or reject special orders at company $X$ is included in the inadequate criteria. The level of earnings growth in Company X is volatile. With the analysis of the application of differential accounting information when company $X$ receives a special order from a customer, the company can decide to accept or reject the order appropriately so that the company's profit increases.
\end{abstract}

KEYWORDS: differential, accounting information, decision making, profit

\section{INTRODUCTION}

In today's modern era accounting is becoming increasingly desirable and increasingly helping in the company's business activities or trading business. Management accounting which is part of accounting has several objectives, one of which is for decision making. Decision making is a process of a systematic approach to choosing alternative whichis most appropriate to solve a problem (Siagian (Hasan, 2002); Atmosudirjo, 1982; James (Hasan, 2002: 10)). In decision making, a phenomenon that is often faced by management is uncertainty. This is because there is a possibility that management in the company is faced with various alternatives that must be chosen and analyzed. In addition, management is also faced with one of the considerations in deciding the best option, which is the impact of the decision on the company's net profit to obtain maximum profit, so management must determine the right selling price (Mulyadi, 2001; Supriyono, 1991; Siahaan, 2007).

Based on observations of company $\mathrm{X}$ in Bandung, this company is often faced with the problem of making decisions on special orders, that is, orders outside of normal sales. These special orders usually ask customers for prices that are lower than the normal selling price 
in this company $\mathrm{X}$, so the company has a dilemma whether this special order will be accepted or not. If the special order is accepted, the company is worried that it will suffer a loss and if it is rejected, the company will risk losing customers. On the other hand, this company has not maximized the capacity of production machines to the maximum, so the company has idle capacity that is not used. Therefore the company must properly analyze the special order, so the company does not lose the opportunity to earn additional profits.

Earnings at company X in Bandung from 2011 to 2015 tend to continue to increase, but in the period 2015 to 2018 experienced fluctuations in profits and decline in profits each year. Especially, in 2015 the company had a profit of Rp.614,322,000.00, then in 2016 the achievement of company profit decreased by Rp.582,435,000.00. Likewise for 2017 the company's profit continues to decline in the amount of Rp 573,232,615.00.

The application of accounting information of company $\mathrm{X}$ in Bandung is also not good because management has difficulty in deciding to accept or reject special orders because the company does not yet have the right calculation in making the decision. In calculating the cost of production, management does not have an accurate accounting calculation. Management only uses general cost estimates to measure the costs incurred and the selling price of a product is determined from the estimated estimated production costs incurred plus the benefits from the estimated estimated production costs using simple and manual analysis.

Based on the description above, it is important for researchers to conduct research relating to the analysis of differential accounting information to assist management in making the right decision when the company gets special orders, so it is expected that maximum profit can be achieved. Therefore, researchers are interested in making the title "Analysis of the Application of Differential Accounting Information in Decision Making Accepting or Declining Special Orders to Increase Company Profit"

In accordance with the background of the study, the issues that will be discussed in this study can be identified as follows:

1) How the application of differential accounting information used by management in making decisions to accept or reject special orders at Company $\mathrm{X}$ in Bandung?

2) What is the level of profit development at company $X$ in Bandung?

3) How the application of differential accounting information can be used by management in decision making to accept or reject special orders so that profits increase at company $\mathrm{X}$ in Bandung

Based on the identification of the problems mentioned above, the purpose of this study is:

1) To explain how the application of differential accounting information in tactical decision making reject or accept special orders at company $\mathrm{X}$ in Bandung

2) To explain the level of profit development at company $X$ in Bandung 
3) To explain the application of differential accounting information can be used by management in making decisions to accept or reject special orders so that profits increase at company $\mathrm{X}$ in Bandung

\section{LITERATURE REVIEW}

Accounting Information Differential Information is one of the important things needed by management in managing the company, so that management can take the right decisions. One important information that is usually needed as a basis for planning and decision making is differential accounting information (Mulyadi, 2001: 17).Differential accounting information is: "information that presents different estimates of income, costs and or assets if a particular action is chosen, compared to other alternative actions" this is stated by Halim and Supomo (2005: 8). Then the definition of differential accounting information stated by Munawir (2002: 305) is: "information costs that will occur in the future (future costs) which are expected to be different for each alternative and useful for management for decision making to choose one of the best alternative actions".

\section{Decision Making Accepting or Refusing a Special Order}

Siagian (Hasan, 2002: 10) states that decision making is: "A systematic approach to the nature of the alternatives faced and taking action which according to the calculation is the most appropriate action. Then there is also the opinion of James (Hasan, 2002: 10) that decision making is "the process used to choose an action as a way of solving problems."Special order decisions as stated by Hansen \& Mowen (2009: 282) focus on the question of whether special prices should be accepted or rejected.Management decisionmaking in making decisions rejecting or accepting special orders is explained by Mulyadi (2001: 149), namely: If differential income (ie additional revenue from receiving special orders) is higher than the differential cost (ie additional costs due to fulfilling the special order), we recommend that you receive these special orders. On the other hand, if differential income is lower than the differential cost, then special orders should be refused.

Differential accounting information can be said to be information that is needed by management, when management faces several alternative solutions to the problem. The information presented in differential accounting consists of differential costs, differential income and differential profits when the company chooses one alternative compared to the other alternatives, making it easier in the decision making process (Halim and Supomo, 2005; Sunarto, 2004; Munawir, 2002).Decision making is a process of a systematic approach to choosing alternative whichis most appropriate for solving a problem (Siagian (Hasan, 2002); Atmosudirjo, 1982: 97; James (Hasan, 2002: 10)).

Decision making taken by management when a company gets a special order must consider differential accounting information, so that management can take the right decision to increase company profits. 
Print ISSN: 2053-4019(Print), Online ISSN: 2053-4027(Online)

Profit is the total income reduced by total costs (Nafarin; 2007, Kuswadi; 2005, Hanafi; 2010, Halim and Supomo; 2005). Based on the description above, it is necessary to analyze the use of differential accounting information when companies get special orders so that the decision to accept or reject these special orders can increase company profits, this research is supported by research conducted by Mustika (2005), Pachori and Sexana (2012), Patarianto (2012), Ishmael and Osamor (2012). The following author presents the picture frame of mind

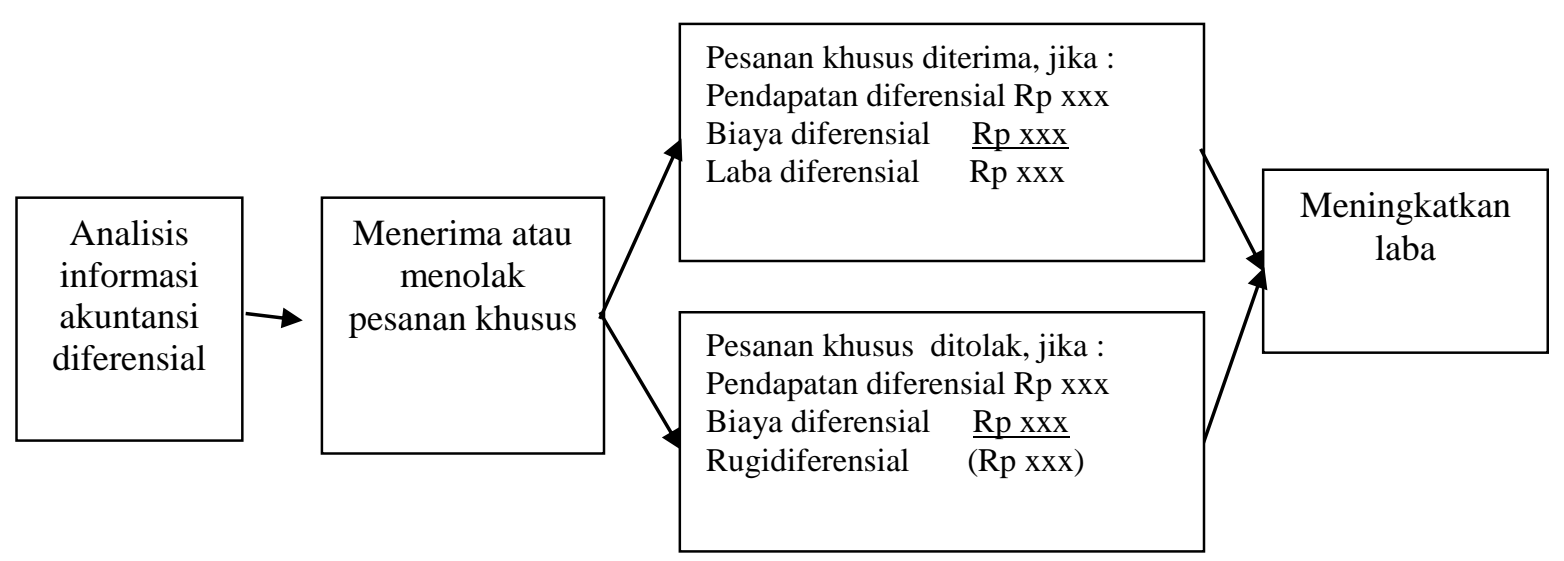

\section{Figure 1: Framework}

\section{METHOD}

Method that will be used in this research is the case study method and descriptive analysis method. Data collection techniques using questionnaires, documentation and interviews. In this study there are two variables, namely differential accounting information in decision making to accept or reject special orders and profits.Data analysis using the Likert scale and continuum lines, as well as for the calculation of the level of development of corporate profits, this study uses the ratio of earnings growth. The rate of profit development is calculated from 2012 to 2018. 
Print ISSN: 2053-4019(Print), Online ISSN: 2053-4027(Online)

\section{RESEARCH FINDINGS AND DISCUSSION}

The results of research using the Likert scale can be described in the continuum line below:

160

\begin{tabular}{|r|r|}
\hline STM & \multicolumn{1}{|c|}{ TM } \\
288 & 416
\end{tabular}

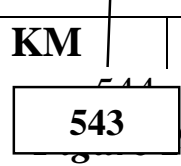
\begin{tabular}{l|r} 
M & SM
\end{tabular}
672800

\section{Continuum Line the Use of Differential Accounting Information in Tactical Decision Making Accept or Refuse Special Orders}

Based on the continuum line shows that the use of differential accounting information to make decisions in accepting or rejecting special orders at company $\mathrm{X}$ in Bandung using a Likert scale obtained a score of 543 with inadequate criteria.

The level of profit growth of company $\mathrm{X}$ in Bandung, is shown in the graph below:level of profit growth of company $\mathrm{X}$

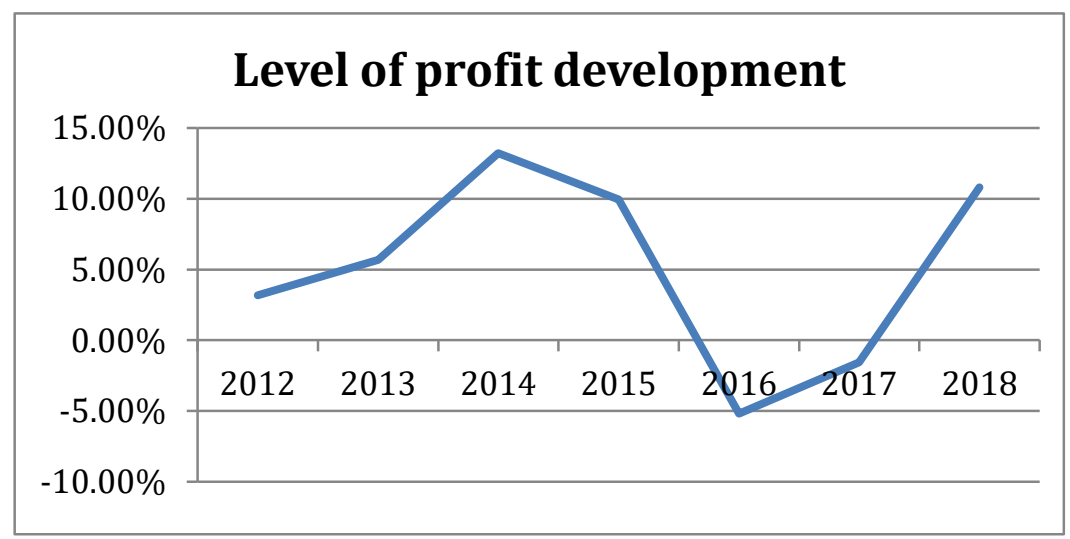

Figure 2 : Graph Level of Profit development

Based on the graph in 2014, company X experienced the highest percentage of profit increase of $13.21 \%$ of profit in 2013 amounting to $\mathrm{Rp}$. 493,532,723.00 to Rp.558,732,612.00 in 2014. The high increase in profit was due to the fact that in 2014 the company conducted intensive marketing such as distributing brochures, entrusting products in stores and packaging beautiful product packaging to attract so that in 2014 the company has a high enough demand, this can increase the number of sales and corporate profits. In 2016 the company experienced a drastic decline in profit development that is $-5.19 \%$, this is caused by various internal company problems so that special orders that In this year, it is often accepted or rejected without going through precise differential analysis calculations, internal problems faced by the company at that time such as poor communication and inconsistency of policies implemented by the company coupled with an increasingly high 
Print ISSN: 2053-4019(Print), Online ISSN: 2053-4027(Online)

level of competition. In 2017 the company can reduce profit decline to $-1.58 \%$ by improving company policy and creating new target markets by diversifying products. Finally, in 2018 the company will again increase its profit up to $10.82 \%$ by marketing via online such as Tokedia, shopee and also selling products in stores, minimarkets. In addition, in 2018 many companies also receive special orders so that companies often get additional profits and can increase company profits.

In November 2018 the company received a special order offer from customers of 300 dozen products at a price of $\mathrm{Rp} 115,000$ per dozen, where the company's normal production capacity for products was 3,850 dozen, while the production plan was 3,500 dozen, so the company had an idle capacity of 350 dozen. Company X products are usually sold at Rp. 126,000 per dozen. Before analyzing, the following is the cost data obtained from company $\mathrm{X}$ internal data in Bandung:

Table.1: Company X Product Costs for November 2018

\begin{tabular}{|l|r|}
\hline \multicolumn{1}{|c|}{ Remarks } & \multicolumn{1}{|c|}{ Total } \\
\hline Production: & Rp. 190678 600 \\
\hline CostsRaw Material Costs & 67.4697 million \\
\hline Direct labor costs & \\
\hline Variable Factory Overhead Costs: & 41.751 million \\
\hline Materials Maid & 9.8152 million \\
\hline Fuels & 9.0635 million \\
\hline Packing & 525,000 \\
\hline Disposal & 19.2612 million \\
\hline Transportation expenses & 2.048 million \\
\hline cost of electricity and water & 847500 \\
\hline Phone Expenses & $4,162,800$ \\
\hline Fees Rupa- Rupa & $87,474,200$ \\
\hline Total Factory Overhead Variable & \\
\hline CostsFixed Factory Overhead Costs: & $2,275,000$ \\
\hline Staff and general & $1,803,500$ \\
\hline Car maintenance & $47,054,200$ \\
\hline Tax & salary $42,975,700$ \\
\hline Total Fixed Factory Overhead Costs & \\
\hline Total Production Costs: & \\
\hline Source: Company X (Data that is & \\
\hline
\end{tabular}

Source: Company X (Data that is reprocessed)

From the data above, the writer presents production costs to company $\mathrm{X}$ before any special 
orders are as follows:

Table 2: Production Costs Company $X$ Before there is a Special Order in November 2018

\begin{tabular}{|l|r|r|}
\hline \multicolumn{1}{|c|}{ Production } & $\begin{array}{c}\text { Costs Production } \\
\text { Costs } \\
\text { Per dozen }\end{array}$ & \multicolumn{1}{|c|}{$\begin{array}{c}\text { Total Production } \\
\text { Costs } \\
\text { (3500 dozen) }\end{array}$} \\
\hline Cost of Raw Materials & Rp. 54,479 & Rp. 190,676,500 \\
\hline Direct Labor Costs & 19,277 & $67,469,500$ \\
\hline Variable Factory Overhead Costs & 24,993 & $87,475,500$ \\
\hline Fixed Factory Overhead Costs & 13,444 & $47,054,200$ \\
\hline Production Costs & Rp. 112,193 & Rp. 392,675,700 \\
\hline
\end{tabular}

Source: Company X (Data Processing Results)

When a company is faced with decision making when the company receives special orders from customers, one of which must be analyzed is differential information. Differential costs are one part that must be analyzed in this special order. Company X operates below normal capacity in other words that company $\mathrm{X}$ has an idle capacity of 350 dozen, so factory overhead costs remain differential costs. Thus, the production costs for special orders for November 2018 are as follows:

Table 3: Production Costs for Special Orders for November 2018

\begin{tabular}{|l|r|r|}
\hline \multicolumn{1}{|c|}{ Production } & $\begin{array}{c}\text { Costs Production } \\
\text { Costs } \\
\text { Per dozen }\end{array}$ & $\begin{array}{c}\text { Total Production Costs } \\
\text { (300 dozen) }\end{array}$ \\
\hline Raw Material Costs & Rp. 54,479 & Rp. 1,6343,700 \\
\hline Direct Labor Costs & 19,277 & $5,783,100$ \\
\hline Variable Factory Overhead Costs & 24,993 & $74.97,900$ \\
\hline Production Costs & Rp. 98,749 & Rp. 29,624,700 \\
\hline
\end{tabular}

Source: Company X (Data Processing Results)

Based on table 2 and table 3, it is known that the total production costs that must be incurred by company $X$ if a special order is received is Rp 98,749. Management must analyze further to see the company's differential profit if the special order is accepted or rejected. Researchers will present a comparative report on the application of differential accounting information for special orders at company $\mathrm{X}$ by looking at the differential profit from regular sales in the presence of additional sales from special orders. The analysis the researchers present in table 4 as follows: 
Print ISSN: 2053-4019(Print), Online ISSN: 2053-4027(Online)

Table 4: Results of Analysis of Differential Accounting Information in Decision Making Accepting or Declining Special Orders at Company X in November 2018

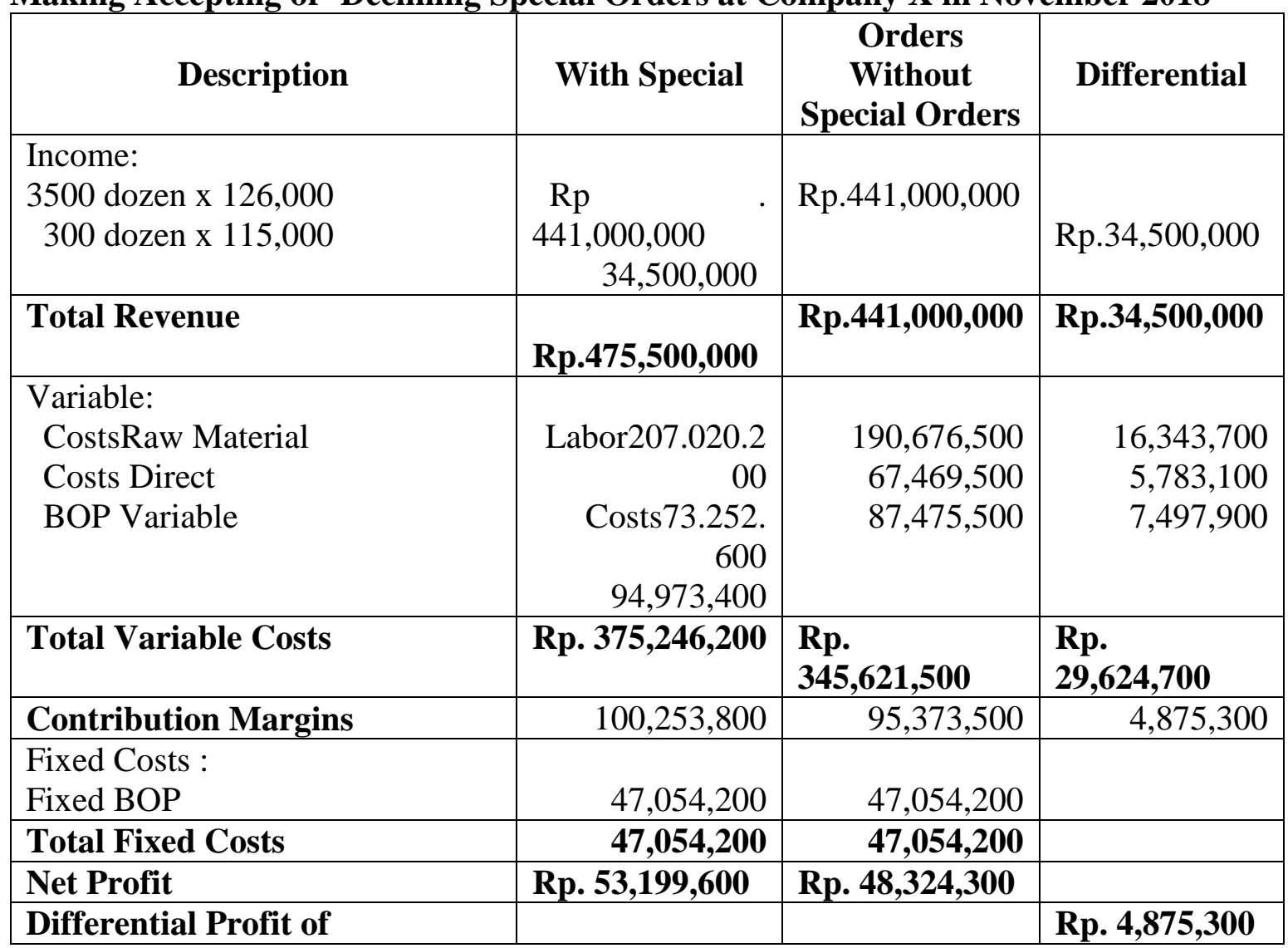

Source: Company X (Data Processing Results)

In table 4 it can be seen that if the company receives the order, the company will get a profit of Rp. 53,199,600, - whereas if the special order is rejected by the company, the company will only receive a profit of Rp.48,324,300. Thus, in November 2018 company X took the decision to accept this special order because the company would get an additional profit of Rp. 4,875,300for this decision. From the results of the analysis of differential accounting information, the right decision can be made by the company, so company profits can increase.

\section{CONCLUSIONS}

Based on the results of research and discussion, the following conclusions can be drawn:

a. The application of differential accounting information in decision making to accept or reject special orders at company $\mathrm{X}$ falls within inadequate criteria. This can be seen from the lack of market separation betweensales regular and special orders at the company and the lack of a differential cost analysis. 
Print ISSN: 2053-4019(Print), Online ISSN: 2053-4027(Online)

b. The level of earnings development in the study period in Company X fluctuates.

c. By analyzing the application of differential accounting information when company $\mathrm{X}$ receives a special order from a customer, company $\mathrm{X}$ can decide to accept or reject the order appropriately so that the company's profit increases.

\section{Suggestion The}

a) company should continue to apply and improve analysis of differential accounting information in its decision making.

b) Companies should maximize production capacity within the company and if there is an idle capacity, the company can more actively utilize the idle capacity to fulfill special orders.

\section{References}

Arikunto, Suhartimi. 2013. Research Procedure: A Practical Approach. Jakarta: Rineka Cipta.

Atmosudirjo, Prajudi. 1982. Administration and Management General. Jakarta: Ghalia Indonesia.

Dinar. 2005. Differential Cost Planning in Decision Making Accepting or Declining Special Orders. Journal, PERBANAS College of Economics, Surabaya. http: //katalog.library. Perbanas.ac.id, accessed on December 13, 2018. Pages 1-18.

Daihani 2001. Computerized Decision Making. Elex Media Komputindo. Jakarta.

Fathoni, 2006, Human Resource Management, Bandung: Rineka Cipta.

Garisson, Ray H and Noreen, Eric W. 2005.Managerial accounting, Eleventh Edition, Translated by: Buri Hinduan and Edward Tanijaya, Salemba Empat, Jakarta.

2006. Managerial Accounting, (translated by Totok Budisantoso). Book I Eleventh Edition. Publisher: Salemba Empat. Jakarta

Gita. 2006. The effect of applying the analysis of differential accounting information in management decision making to accept or reject special orders on company profits. Sam Ratulangi University Manado FEB. Manado

Halim, Abdul, and Supomo, Bambang. 2005. Management Accounting. Yogyakarta: BPFE.

Hanafi, Mahmud M. 2010. Financial Management. Fifth Matter. Yogyakarta: BPFE.

Hansen and Mowen. 2009. Managerial Accounting Book 1 Issue 8 Translation by Deny Arnos Kwary. Salemba Empat. Jakarta.

\section{Empat}

. 2011. Managerial AccountingAccountingBook 2.2. Jakarta Edition: Salemba

Hasan, M. Iqbal. 2002. Main Material Research Methodology and Its Application, Ghalia Indonesia. Bogor

Ishmael and Osamor. 2012. This research is sourced from the Australian Journal of Business and Management Research Vol.2, No. 03, 2012. The journal aims to examine the concept of relevant costs

Iskandar. 2009. Educational and Social Research Methodology (Quantitative and Qualitative).Jakarta: GP Press.

Janner, Simarmata. 2010. Software Engineering. Yogyakarta: Andi Publisher. 
Print ISSN: 2053-4019(Print), Online ISSN: 2053-4027(Online)

Kasiram, Moh. 2008. Research Methodology. Malang: UIN-Malang Press.

Cashmere. 2011. Analysis of Financial Statements. Jakarta: Rajawali. . 2014. Banks and Other Financial Institutions. Revised Edition, Fourteenth Printing, PT. RajaGrafindo Persada, Jakarta.

Christianity. 2002. Accounting Information Systems. AMP YKPN.Yogyakarta Publishing and Printing Unit.

Kuswadi. 2005. Increasing Profit Through Financial Accounting and Cost Accounting Approaches. PT. Elex Media Komputindo. Jakarta.

Lubis, Irsyad, 2010. Banks and Other Financial Institutions, Issue 1. Medan: USU Press.

Mulyadi. 2001. Management Accounting: Concepts, Benefits and Engineering. Third Edition. First printing. Salemba Empat. Jakarta.

2005. Cost Accounting. Fifth edition. Yogyakarta:UPPAMP YKPN Gadjah Mada University.

Munawir.2002. Financial and Management Accounting. Revised Edition. BPFE Publisher. Yogyakarta. 2002. Financial Statement Analysis. Yogyakarta: Liberty

Mustika. 2005. The Effect of Analysis of Differential Accounting Information in the Decision of Accepting or Rejecting Special Orders to Increase Company Profit. Thesis.Widyatama University, Bandung. http://repository.widyatama.ac.id/xmlui/handle/10364/732, accessed 11 November 2018. Pg 1-105.

Nafarin, M. 2007. Corporate Budgeting. Salemba Empat. Jakarta.

Pachori, and Saxena. 2012. The journal aims to help India's automotive industry keep up with the competition competition in the automotive industry with the help of relevant costs in the decision making process.

Patarianto. 2012. Journal of Media Mahardika Vol. 10, No. 3, 2012. The journal uses cost accounting principles to decide whether to accept or reject orders with variable costing methods.

Prawironegoro, Darsono. 2008. Corporate Budgeting. Media Discourse Partner. Jakarta. . 2009. Management Accounting. Third Edition, Media Discourse Partner Publishers. Jakarta.

Sawir.2009. Financial Performance Analysis and Corporate Financial Planning.Jakarta: PT. Gramedia Main Library.

Now, Uma and Roger Bougie. 2013. Research Methods for Business A Skill Building Approach. West Sussex: John Willey \& Sons

Siahaan. 2007. Risk Management. PT. Elex Media Komputindo. Jakarta.

Simarmata and Prayudi. 2010. Database. Yogyakarta: Andi

Sunarto. 2004. Management Accounting. Yogyakarta: Andi Offset.

Sugiyono 2009. Quantitative, qualitative and $R \& D$ research methods. Bandung: Alfabeta. Supomo, Bambang, and Indriantoro, 2002, Business Research Methodology, Second Printing, Yogyakarta; UGM BPFE Publisher.

Supriyono, 2001. Management Accounting, First Edition, Yogyakarta: BPFE. . 2011. Cost Accounting Cost Collections and Determination of Cost.Book 1 
European Journal of Business and Innovation Research

Vol.8, No.3.pp. 17-27, May 2020

Published by ECRTD-UK

Print ISSN: 2053-4019(Print), Online ISSN: 2053-4027(Online)

Edition 2. Yogyakarta: BPFE.

Susanto. 2005. World Class Family Business. Semarang: Quantum Business and Management

Syamsuddin. 2009. Corporate Financial Management. PT. Raja Grafindo Persada. Jaka 
